\title{
Regulation of synthesis and secretion of the lipoprotein by cultured eel hepatocytes
}

\author{
SEICHHAYASHI \\ Faculty of Fisheries, Kagashima University, 450-20 Shimoarata, Kagoshima 890-0056, Japan (hayashi@ fishkagoshima- uac.jp)
}

SUMMARY: Eel hepatocytes actively syntesize and secrete a lipoprotein. It consists of about $60 \%$ triacylglycerol and $10 \%$ protein, and main apolipoproteins are apoB and apoA tis average particle size is $750 \mathrm{~nm}$. These characteristics show it is a chylomicron llike lipoprotein. Thyroxine (T4) at $10^{8} \mathrm{M}$ activates the lipid synthesis in the hepatocytes and increases hepatocellular lipid. The synthesis of the chylomicron like lipoprotein is also stimulated by T4, but T4 does not affect the synthesis of other secreted proteins. T4 speciically stimulates the synthesis of the lipoprotein. Though docosahexaenoic acid (DHA) stimulates lipid synthesis in the hepatocytes, DHA inhibits the synthesis and secretion of the lipoprotein. However, DHA does not inhibit the synthesis of other secreted proteins. DHA specifically inhibits the synthesis and secretion of the lipoprotein, but eicosapentaenoic acid does not inhibit. HDL specifically binds HDL-binding protein (HBP) of the plasma membrane. The binding of HDL to the hepatocytes is saturated at concentrations over $100 \mu \mathrm{g} \mathrm{HDL} / \mathrm{ml}$ and $\mathrm{Kd}$ value is $20 \mu \mathrm{g} \mathrm{HDL} / \mathrm{ml}$. HDL and apoAl are ligands of HBP. We suppose that HDL and tree apoAl in eel serum take part in lipid transport through the mediation of the HBP.

\section{KEYWORDS. hepatocytes, thyroxine, HDL, HDL-binding protein, DHA, EPA}

\section{INTRODUCTION}

Cultured eel hepatocytes actively synthesize and secrete a chylomicron-like lipoprotein. In mammals chylomicron is synthesized and secreted by epithelial cells of small intestine. However, the characterization of the secreted lipoprotein by eel hepatocytes is chylomicron-like in its apolipoprotein component, particle size and chemical composition. This unique lipoprotein is synthesized and secreted under hormonal regulations, such as insulin, thyroxine, and estradiol, whilst serum very low-density lipoprotein (VLD) and high-density lipoprotein (HDL) affect its synthesis and secretion. Furthermore, dooosahexaenoic acid (DHA) and eicosapentaenoic acid (EPA) affect the synthesis and secretion.

\section{PRIMARY CULTURE OF EEL HEPATOCYTES}

Eel (Anguilla japonica) hepatocytes are prepared by collagenase digestion of a perfused liver as reported by Hayashi and Ooshiro") and Hayashi and Komatsu ${ }^{2}$ Average yield of isolated hepatocytes is $10^{8}$ cells per $\mathrm{g}$ liver. Isolated hepatocytes are cullured in William's medium $\mathrm{E}$ ( $\mathrm{pH} 7.4)$ containing $5 \%$ fetal bovine serum (FBS), insulin $(0.16 \mu \mathrm{M}), \mathrm{NaHCO}_{3}(23 \mathrm{mM})$, penicillin $(70 \mu \mathrm{g} / \mathrm{ml})$, and streptomycin $\left.(100 \mu \mathrm{g} / \mathrm{ml})^{2.3}\right)$ Hepatocytes of cap (Cyprinus carpio), rainbow trout (Oncorhynchus mykiss)," salmon (Oncorhynchus keta), "channel caffish (Ictalurus punctatus), ${ }^{7}$ tilapia (Oreochromis niloticus), and Indian calfish" are also cultured.

Eel hepatocytes hardly attach on a dish if culture dishes are not preooated with fibronectin $\left(5 \mu \mathrm{g} / \mathrm{cm}^{2}\right)$ or poly-L-lysine $(50$ $\mu \mathrm{g} / \mathrm{cm}^{2}, 0.02 \%$ solution). ${ }^{2.1()}$ Collagen coating is not useful for attachment of eel hepatocytes. However, carp hepatocytes can attach on a dish precoated with collagen ${ }^{4)}$ Comparison of trout hepatocyte calture on different substrates was reported. ${ }^{\text {i) }}$

Eel hepatocytes can be caltured in FBS-free William's medium ${ }^{10}$ The medium consists of William's medium $E$, insulin $(10 \mu \mathrm{g} / \mathrm{ml})$, glucagon $(1 \mu \mathrm{g} / \mathrm{ml})$, epidermal growth factor (50 $\mathrm{ng} / \mathrm{ml})$, prolactin $(20 \mathrm{mU} / \mathrm{ml})$, growth hormone $(10 \mathrm{mU} / \mathrm{ml})$, $\mathrm{NaHOO}_{3}(24.5 \mathrm{mM})$, penicillin (70 $\left.\mathrm{\mu g} / \mathrm{ml}\right)$, and streptomycin $(100 \mu \mathrm{g} / \mathrm{ml})$. Insulin-deficient medium, particularly, affects the morphology and viability. The morphology was spherical during 11 days culture in insulin-deficient medium and the number of living cells was $53 \%$ of that of control cells. ${ }^{10)}$

Fish liver has many important functions similar to those of mammalian livers. Perfused livers and isolated liver cells are available for investigation of gluconeogenesis. ${ }^{1,12)}$ Lipogenesis ${ }^{13)}$ and synthesis and secretion of senum proteins ${ }^{14)}$ were investigated in cultured eel hepatocytes. Induction, synthesis, and secretion of vitellogenin by cultured hepatocytes of rainbow trout and eel was reported by Meiter t $\mathrm{L}^{15)}$ and Kwon and Mugiya, ${ }^{16)}$ respectively. Induction of detoxification enzyme of $\mathrm{P} 450$ was also investigated by using caltured hepatocytes of rainbow trout ${ }^{17}$ and of Indian catfish. $^{9}$

CHARACTERIZATION OF LPOPROTEIN
SECRETED BY CULTUREDEEL HEPATOCYTES


Main apolipoproteins of the secreted lipoprotein are apoB48, apoAI, and apoAII It is known that chylomicron of mammals contains apoB48 and apoAI as the main apolipoproteins. Chemical composition of the lipoprotein secreted by eel hepatocytes is triacylglycerol (TG,69.0 $\pm 5.1 \%$ ), phospholipid (PL,14.7 $\pm 2.9 \%$ ), protein (12.0 $\pm 4.8 \%$ ), free cholesterol (FC, 3.8 $\pm 0.3 \%$ ), and cholesteryl ester (CE, $0.36 \pm 0.50 \%$ ). TG is a main component, as that in mammalian chylomicron, but the protein ratio is rather higher than that of the chylomicron. The higher content of the protein reflects the density of the secreted lipoprotein, which is $0.95<\mathrm{d}<1.063$. The mean particle size is $750 \mathrm{~nm}$ diameter. This particle size is almost the same size as that of the chylomicron.

The secreted lipoprotein by cultured eel hepatocytes is different from eel serum lipoproteins. Eel senum lipoproteins consist of two main lipoproteins. One is VLDL and the other is HDL The VLDL contains apoAI and apoAII besides apoB48 as main protein components and $\mathrm{TG}$ as main lipid. This characterization is the same as that of the secreted lipoprotein. The HDL consists of apoAI and apoAII and contains PL and cholesterol (CH) as main lipid. As Babin and Vemier ${ }^{18)}$ reported, HDL is predominant lipoprotein in plasma of many fishes.

\section{EFFECT OFTHYROXINE}

Thyroid hormone is known to induce synthesis of lipogenic enzymes, malic enzyme, acetyl CoA carboxylase and fatty acid synthetase, in a liver. Promoting synthesis of lipogenic enzymes was confimed by caltured hepatocytes with thyroid hormone ${ }^{19)}$ and by in vivo experiments. ${ }^{x}$ ) We then investigated whether stimulation of lipid synthesis by thyroid homone induced promoting lipoprotein synthesis and secretion. ${ }^{13)}$

Eel hepatocytes aultured with $10^{8} \mathrm{M}$ L-thyroxine (T4) for 6 days synthesized lipids from ${ }^{14} \mathrm{C}$-acetate at a higher rate than control cells cultured without T4, and particularly $\mathrm{CH}$ and PL syntheses were stimulated about 2-fold. Quantities of $\mathrm{CH}$, PL, and TG in the hepatocytes were also increased by T4 and the efflux of lipids into the culture medium was stimulated. Because cultured eel hepatocytes secrete only one kind of lipoprotein, a chylomicron-like lipoprotein, all lipids in the medium associate with the secreted lipoprotein. Therefore, the stimulatory effect of $\mathrm{T} 4$ on the efflux of lipids into the calture medium seems due to the stimulatory effect of $\mathrm{T} 4$ on synthesis and secretion of lipoprotein. When the hepatocytes were incubated with ${ }^{3} \mathrm{H}$-leucine and ${ }^{14} \mathrm{C}$-acetate, the incorporation of ${ }^{3} \mathrm{H}$-leucine and ${ }^{14} \mathrm{C}$-acetate into the secreted lipoprotein in the presence of $\mathrm{T4}$ increased significantly compared to that of the control. However, the incorporation of ${ }^{3} \mathrm{H}$-leucine into the proteins except lipoprotein was not different between T4-treated and control cells. These results suggest that eel hepatocytes cultured with T4 stimulate specifically synthesizing and secreting the lipoprotein.

Many reports on thyroid homone effect are consistent with stimulatory effect on lipogenesis in the liver, but the effect on lipoprotein synthesis and secretion is unclear. Daily injoction of triiodothyronine (T3) to rats over a period of 6 days led to increases in senum TG and hepatic mRNA level for apoAl ${ }^{21)}$ Contrary to this, perfused livers from rats injected $T 3$ reduced VIDL synthesis and secretion ${ }^{2)}$ and TG synthesis and efflux. ${ }^{2)}$ We suggest that the primary function of T4 in eel hepatocytes is stimulation of lipogenesis and not stimulation of synthesis and secretion of lipoprotein. We consider that the stimulation of lipoprotein synthesis and secretion seems due to the increased lipids in the hepatocytes. Because the increased lipids caused by addition of eel serum VLDL or HDL to cultured eel hepatocytes induce the stimulation of lipoprotein synthesis and secretion. ${ }^{24}$ In any experiments of the addition of serum VLDL, HDL or T4 to cultured eel hepatocytes, the increased lipid in the hepatocytes is PLand CH.

Thyroid hormone in teleosts is concemed with their migration and spawning circulating concentrations of T4 in salmonids was reported during their migration ${ }^{25)}$ and spawning. ${ }^{26)}$ When juvenile salmonids in the river migrate to the sea, their concentration of T4 increased. Contrary to juvenile salmonids, when salmonids grown in the sea migrate to the river for spawning their concentration of T4 decreases from $1.5 \times 10^{8} \mathrm{M}$ to below $0.7 \mathrm{x}$ $10^{8} \mathrm{M}^{26}$ Juvenile eels migrate from the sea to the river and eels grown in the river migrate to the sea for spawning, contrary to salmonids. If the increase of T4 concentration in eel senum induces the migration to the sea, stimulation of lipogenesis and the lipoprotein synthesis and secretion in the liver by $\mathrm{T} 4$ is supposed to reserve energy source for the migration.

\section{HDL BINDING PROTEIN}

Although the function of HDL binding protein is still unclear, ${ }^{27}$ its presence of plasma membranes of cells such as hepatocytes, epithelial cells of small intestine ${ }^{29)}$ and platelets ${ }^{3)}$ has been confirmed The cloning of the HDL binding protein was reported ${ }^{31)}$ We demonstrated the specific binding of serum $H D L$ to eel hepatocytes by using a fluorescent lipophilic dye labeled $\mathrm{HDL}^{32)}$ The dye is N,N-dipentadecylaminostyrylpylidinium iodide (di-15-ASP). Freshly isolated hepatocytes bind to di-15-ASP-HDL under the incubation at $0{ }^{\circ} \mathrm{C}$ for $2 \mathrm{~h}$ under the dark, the fluorescence of the cells bound to it can be detected by a flow cytometer. Unlabeled HDL inhibits the binding. The binding of di-15-ASP-HDL to the hepatocytes is saturated at concentrations over $100 \mu \mathrm{g} H \mathrm{HDL}$ protein/ml and $\mathrm{Kd}$ value is 20 $\mu \mathrm{g} \mathrm{HDL}$ protein/ml. The Kd value is almost the same as those of rat liver ${ }^{31)}$ and epithelial cells of rat intestine, ${ }^{27)}$ which are 10 to 50 $\mu \mathrm{g} / \mathrm{ml}$

HDL binding protein (HBP) is isolated from the microsomal fraction of eel liver homogenate by affinity chromatography with a HDL-column. ${ }^{33)}$ The HBP isolated by a HDL-oolumn consists of at least three proteins with low molecular weights of 185,145 and $13.5 \mathrm{kDa}$; the main component is $14.5 \mathrm{kDa}$. These products are not products of protease digestion, as the procedure was 
carried out in the presence of protease inhibitors including (p-aminophenyl) methansulfonyl fluoride, 4-(2-aminœethyl)-benzenesulfonyl fluoride, pepstatin A, E-64, bestatin, leupeptin, aprotinin and EDTA The HBP specifically binds to FIIC-apoAI and faintly binds or does not bind to FITC-apoAIL Furthermore, binding of di-15-ASP-HDL to isolated eel hepatocytes is inhibited by the antibody to apoAI, but not inhibited by the antibody to apoAII. These results strongly suggest that the HBP isolated from the microsomal fraction is present on the plasma membrane of eel liver. On the other hand, we demonstrated the presence of free apoAI in the eel serum and that free apoAI is secreted in the culture medium by cultured eel hepatocytes. ${ }^{34)}$ Therefore, we can suppose that HDL and free apoAI in eel serum take part in lipid transport through the mediation of the HBP.

\section{EFFECT OF DHAANDEPA}

The first characteristic on the effect of DHA or EPA is that hepatocellular lipid synthesis is stimulated by DHA. DHA at 1 $\mathrm{mM}$ increased lipogenesis from ${ }^{14} \mathrm{C}$-acetate by 3.5 fold and the hepatocellular TG, FC, and CE syntheses increased 9.7, 1.6, and 8.5 fold, respectively. ${ }^{33}$ Furthermore, addition of $1 \mathrm{mM} \mathrm{DHA}$ to the cultured hepatocytes increased the amount of hepatocellular lipid such as TG, PL, and CH significantly compared to that of control cells. Particularly, the TG increased 4.8 fold in DHA treated cells. Similarly, EPA at $1 \mathrm{mM}$ increased hepatocellular lipid by 1.64 fold

The second characteristic is that DHA inhibits the secretion of the lipoprotein. When DHA treated cells were incubated with ${ }^{14} \mathrm{C}$-acetate and ${ }^{3} \mathrm{H}$-leucine, the incorporation of ${ }^{14} \mathrm{C}$ and ${ }^{3} \mathrm{H}$ into the lipoprotein reduced to 55 and $60 \%$, respectively, compared to those by control cells. However, DHA did not affect the incorporation of ${ }^{3} \mathrm{H}$-leucine into other secreted proteins and the hepatocellular proteins. ${ }^{36}$ Though the incorporation of ${ }^{14} \mathrm{C}$-acetate into the secreted lipoprotein was reduced by DHA, the distribution of radioactivity between TG, PL, FC, and CE of the secreted lipoprotein was the same between DHA treated and control cells. The amount of the lipoprotein secreted by $1 \mathrm{mM}$ DHA treated cells was $16.6 \%$ of that by control cells, but the chemical composition of the lipoprotein was also the same between the DHA treated and controls. Similarly, the profile of apolipoproteins determined from protein staining or autoradiogram after SDS-PAGE of the lipoprotein was the same between the DHA and controls. It was reported that DHA and EPA stimulated degradation of apoB protein and this degradation was the reason to reduce lipoprotein secretion since apoB is essential for lipoprotein assembly. ${ }^{30}$ The lipoprotein secreted by eel hepatocytes contains apoB corresponding to apoB48 as a main apolipoprotein, but the high specific activity of the apolipoproteins including apoB48 secreted by DHA treated cells would be difficult to explain the increase of apoB48 degradation. Recently, we confirmed that apoB48 detected by immunoblotting was much more present in the hepatocytes treated with DHA than in the control cells. Inhibition of the lipoprotein secretion by DHA seems due to inhibition of secretion itself and does not due to apoB48 degradation.

\section{ACKNOWLEDGMENT}

The research was supported in part by a grant-in-aid from the Ministry of Education, Sciences, Sports and Culture of Japan.

\section{REFERENCES}

1. Hayashi S.Ooshiro Z Gluconeogenesis and glyoolysis in isolated perfised liver of the eel. Bull Japan.Soc.SciFish. 1975; 41: 201 208.

2. Hayashi S. Komatsu M. Primary culture of eel hepatocytesSynthesis and secretion of lipoprotein In Doyle A Griffithes JB. Newell DG. (eds) Cell\&Tissue Culnure:Laboratory Procodure John Wiley \& Sons, Chichester, New York, 1998, pp23A2 •1$2 \cdot 10$.

3. Hayashi S. Ooshimo Z. Primary culture of the freshly isolated liver cells of the eel BullJapxon Soc.SciFish 1985; 51: 765 771.

4. Sato M. Hayashi S. Kakimoto D. Metabolism of thiamine in capp.Nuppon Suisan Gakkaishi 1993; 59: 1085-1091.

5. Klaunig JE Ruch RJ, GoldblattPJ. Trout hepatocyte culture. In Vtro CellDenBiol. 1985; 21:221-228.

6. Mommsen TP. Lazier CB. Stimulation of estrogen roceptor accumulation by estradiol in primary aultures of salmon hepatocytes. FEBSLETTERS 1986; 195: 269-271.

7. Seddon WL Proser CL Non-enzymatic isolation and allure of channel calfish hepatocytes. Comp.BiochemPhysiol. 1999; 123A 9-15.

8. Schmid AC. Reinecke M. Kloas W. Primary cultured hepatocytes of the bony fish, Oreochromis massambiaus, the tilapia. J.Endocinol. 2000, 166: $265-273$.

9. Ghosh MC. Ghosh RRay AK. Induction of CYP1A by carbofuran in primary culture of fish hepatocytes. JBiochemMolTaxicol 2000; 14: 204209.

10. Hayashi S. Ooshim Z Primary culture of the eel hepatocytes in the senum-free medium BullLIapanSocSCiFish. 1986; 52: 1641-1651.

11. Lipsky MMSheridan TR. Bernett RO. May EB. Comparison of trout hepalocyte culture on different substrates. InVitro Cell.DevBiol. 1986; 22 : 360-362.

12. Hayashi S. Ooshiro Z Guconeogenesis in isolated liver cells of the eel (Angrilla japonica).J.Comp. Physiol.1979; B132:343-350.

13. Ndiaye D. Hayashi S. Stimulatory effect of thyroxine on lipogenesis and lipoprotein synthesis by cultured eel hepatocytes. Fish Scie. 1997; 63: 304309.

14. Yu FG. Ando S. Hayashi S. Characterization of lipoprotein secreted by cultured eel hepatocytes and its comparison with serum lipoproteins. Cell Struct Funct. 1991; 16:347-355.

15. Mairre $\mathrm{JL}$ Valotaire Y. G-Guillouzo C. Estradiol-17ß stimulation of vitellogenin synthesis in primary culture of male rainbow trout 
hepatocytes. In Vito Cell.DevBiol. 1986; 22: 337-343.

16. Kwon HC. Mugiya Y. Involvement of growth hormone and prolactin in the induction of vitellogenin synthesis in primary hepatocyte culture in the el, Anguilla japonica. Gen Comp.Endocrinol. 1994; 93:51-60.

17. Pesonen M.Goksoyr A Anderson T. Expression of P450 $1 \mathrm{Al}$ in a primary aulhure of rainbow trout hepatocytes exposed to $\beta$-naphthoflavone or 23,7,8-tetrachlorodibenzo-p-dioxin. Arch Biochem Biophys. 1992; 292: 228-233.

18. Babin PJ. Vemier JM. Plasma lipoproteins in fish.J.Lipid Res. 1989; 30. $467-489$.

19. Goodridghe G. Adolman TG. Regulation of malic enzyme synthesis by insulin, triodothyronine, and glucagon in liver cells in culture. JBiol Chem. 1976;251:3027-3032.

20. Blennemann B. Moon YK. Freake HC. Tissuespecific regulation of fatty acid synthesis by thymid hormone. Endocrinology 1992; 130: $637-643$.

21. Apostolopoulos JJ. Marshall JF. Howlett GJ. Trïodothyronine increases rat apolipoprotein A-I synthesis and alters high-density lipoprotein composition in vivo. ExrJ.Biochem. 1990, 194: 147-154.

22. Wiloox HG. Heimberg M. Effects of hyperthyroidism on syntheris, secretion and metabolism of the VLDL apolipoproteins by the perfised rat liver BiochimBiophys Acta 1991; 1081:246-252.

23. Olubadewo J. Morgan DW. Heimberg M. Effect of triiodothyronine on biosynthesis and secretion of triglyceride by livers perfused in vivo with $\left[{ }^{3} \mathrm{H}\right]$ oleate and $\left.{ }^{14} \mathrm{C}\right]$ glyoerol.J.Biol Chem. 1983; 258: 938-945.

24. Yu FG. Ando S. Hayashi S. Effects of insulin, eel serum very low density lipoprotein, and high density lipoprotein on lipoprotein synthesis and secretion by cullured hepatocytes of eel (Anguilla japonica). Comp.BiochemPhysiol. 1992; 101B:333-339.

25. Ura K. Hara A. Yamacti K. Serum thyroid homone, guanine and protein profiles during smoltification and after thyroxine treatment in the masu salmon, Onoorhynchus masou. Comp.Biochem. Physiol. 1994; 107A: $607-612$.

26. Ueda H. Hiroi O. Hara A. Yamauchi K Nagahama Y. Changes in serum concentrations of sternid homones thymoxine, and vitellogenin during spawning migration of the chum salmon, Oncorkynchus keta. Gen Comp.Endocinol. 1984; 53:203-211.

27. Ailhaud G. Cellular signal transcucts: a new role of $\mathrm{HDL}$ Curr. Opin Lipidol. 1992; 3:222-226.

28. Hidaka $\mathrm{H}$. Fidge NH Affinity purification of the hepatic high-density lipoprotein receptor identifies two acidic glycoproteins and enables further characterization of their binding properties. BiochemJ. 1992; 284 : 161-167.

29. Ragler G. Herols G. Stange EF. HDL3-retroendocytosis in culthmed small intestinal crypt cells. BiochimBiophys Acta 1991; 1095: $30-38$.

30. Nofer JR Walter M. Kehrel B. Scedorf U. Assmann G. HDL3 activates phospholipase $\mathrm{D}$ in nomal but not in glycoprotein Ib/llla deficient platelets. BiochemPiophys Res Commm. 1995; 207: 148-154.

31. Fidge $\mathrm{NH}$ High density lipoprotein receptors, binding proteins, and ligand.J.Lipid Res. 1999, 40: 187-201.

32. Ndiaye D. Mori Y. Tanaka Y. Sakata T. Miki H. Sakakibara T. Sato M. Hayashi S. Effect of specific binding of high density lipoprotein to eel hepatocytes on their secretion of lipoprotein. Cell Sinuct Funct. 1995; 20:
301-310.

33. Katoh H. Ge YP. Tsuda T. Hayashi S. High density lipoprotein binding protein of eel (Anguilla japonica) liver with specificity of binding to apoAl as a ligand. Comp.BiochemPhsyiol.2001;B129:843-852

34. Katoh H. Ge YP. Ndaiaye D. Hayashi S. Distribution of apolipopoteins A-I and A-II in serum, secreted proteins by cultured hepatocytes, and the plasma membrane of hepatocytes in eel. Fish Scie. 2000; 66: 579-585.

35. Ndiaye D. Hayashi S. Effect of docosahexaenoic acid on lipoprotein synthesis and secretion by cultured eel hepatocytes. Cell Sinuct Funct. 1996; 21:307-315.

36. Wang $H$. Chan $X$. Fisher EA N-3 Fatty acids stimulate intracellular degradation of apoprotein B in rat hepatocytes. J.Clin.Invest. 1993; 91: $1380-1389$. 